Article

\title{
Structural Changes of Oak Wood Main Components Caused by Thermal Modification
}

\author{
Ivan Kubovský *, Danica Kačíková and František Kačík@ \\ Faculty of Wood Sciences and Technology, Technical University in Zvolen, T.G. Masaryka 24, 96001 Zvolen, \\ Slovakia; kacikova@tuzvo.sk (D.K.); kacik@tuzvo.sk (F.K.) \\ * Correspondence: kubovsky@tuzvo.sk
}

Received: 7 January 2020; Accepted: 18 February 2020; Published: 21 February 2020

\begin{abstract}
Thermal modification of wood causes chemical changes that significantly affect the physical, mechanical and biological properties of wood; thus, it is essential to investigate these changes for better utilization of products. Fourier transform infrared spectroscopy and size exclusion chromatography were used for evaluation of chemical changes at thermal treatment of oak wood. Thermal modification was applied according to Thermowood process at the temperatures of 160 , 180 and $210^{\circ} \mathrm{C}$, respectively. The results showed that hemicelluloses are less thermally stable than cellulose. Chains of polysaccharides split to shorter ones leading to a decrease of the degree of polymerization and an increase of polydispersity. At the highest temperature of the treatment $\left(210^{\circ} \mathrm{C}\right)$, also crosslinking reactions take place. At lower temperatures degradation reactions of lignin predominate, higher temperatures cause mainly condensation reactions and a molecular weight increase. Chemical changes in main components of thermally modified wood mainly affect its mechanical properties, which should be considered into account especially when designing various timber constructions.
\end{abstract}

Keywords: oak wood; thermal treatment; degradation; infrared spectroscopy; size-exclusion chromatography

\section{Introduction}

Wood is a sustainable and environmentally friendly natural material used for both structural and non-structural applications. It has excellent mechanical properties. However, one of the main disadvantages of wood is its hygroscopicity causing dimensional instability. Particularly the outdoor utilization of wood is highly limited by its strong hygroscopicity and low durability [1,2]. A thermal modification is also used in addition to the chemical modification to improve the dimensional stability of wood. Thermal modification (TM) is environmentally friendly and one of the most effective pretreatment methods to enhance the dimensional stability and decay resistance of wood without using any toxic chemicals. The heat applied ranges between 160 to $260{ }^{\circ} \mathrm{C}$ in a vacuum, nitrogen, air or oil environments [3,4]. Thermal modification causes changes in the structure of wood cell wall polymers, which is reflected in a change in its properties. Heat treatment conditions have a direct effect on the chemical decomposition of wood [5]. Wood is a complex biological material and the thermal decomposition of its main components (hemicellulose, cellulose and lignin) occurs through a series of chemical reactions. The modified wood composition results in a lower hygroscopicity with a major influence on both dimensional stability and durability [6]. It appears that the higher the treatment temperature, the better the durability, stability and biological properties of the product become. However, it should be noted that the overall mechanical properties of wood are weakened under such conditions $[7,8]$. The most sensitive of the structural components to thermal degradation are hemicelluloses. Acetic and formic acids arising during thermal treatment enhance 
hydrolysis of hemicelluloses and cellulose. The degree of polymerization of polysaccharides decreases, hydrolyzed sugars are further dehydrated, and a wide variety of volatile compounds is formed, such as formaldehyde, furfural, hydroxymethylfurfural and other aldehydes $[9,10]$. Cellulose crystallinity increases with thermal modification due to the degradation of its amorphous part, which is related not only to the temperature but also to the length of thermal treatment [11,12].

The chemical changes that occur in wood heat treatment process are affected by many external conditions (temperature, heating time, type and composition of the surrounding atmosphere). It is important to note that many competitive reactions are taking place simultaneously and are significantly influenced by the conditions of the thermal treatment. This is one of the reasons why several authors have come to different results in the investigation of heat-treated wood experiment.

As assumed the thermal treatment process of wood causes modifications and degradations in its main components. These processes occur through various reactions such as dehydration, hydrolysis, oxidation, decarboxylation and trans-glycosylation [13]. Several changes were observed in the FTIR spectra (Figures 1-3), which were assigned to changes in the hemicellulose and lignin structures. Changes in the thermally treated oak wood, related to color and mechanical changes were described and analyzed in detail in several authors' works $[4,14,15]$. In our study, we will focus on changes in main oak wood components isolated (extracted) from individual thermally treated samples.

The goal of this study is to examine the chemical changes of oak wood main components by Fourier-transform infrared spectroscopy (FTIR) and size exclusion chromatography (SEC), in thermally modified wood in order to clarify the processes of structural changes in wood polymers better.

\section{Materials and Methods}

\subsection{Samples Preparation}

The experimental material consisted of samples of European oak (Quercus robur, L.) in dimensions of $200 \mathrm{~mm} \times 100 \mathrm{~mm} \times 20 \mathrm{~mm}$ (longitudinal $\times$ tangential $\times$ radial). All samples were air-conditioned under specific conditions ( $\mathrm{RH} 65 \% \pm 3 \%$ and temperature $20 \pm 2{ }^{\circ} \mathrm{C}$ ) for more than 6 months to achieve an equilibrium moisture content (EMC) of $12 \%$. After conditioning procedure were selected forty samples without visible defects and divided into four groups (each includes of ten samples). The first group served as a reference and was not heat treated. The remaining three groups were thermally modified at atmospheric pressure using three peak temperatures $\left(160,180\right.$, and $\left.210^{\circ} \mathrm{C}\right)$ according to [4]. The entire thermal treatment process involves three phases. The first phase concerns fast preliminary heating up to ca $100{ }^{\circ} \mathrm{C}$ followed by a slower temperature increase to $130{ }^{\circ} \mathrm{C}$, the second phase represents slow heating period to $160-210^{\circ} \mathrm{C}$ for $2-3 \mathrm{~h}$ and during third phase is wood cooled and its moisture content is stabilized on about $4-7 \%$. Depending on the temperature of heat treatment these groups were further referred as " 20 " (untreated), " 160 ", " 180 " and " 210 ". The heat treated and untreated samples were then mechanically disintegrated and milled to a particle size of 200-300 $\mu \mathrm{m}$ using a POLYMIX PX-MFC 90D laboratory mill (Kinematica, Luzern, Switzerland) and dried (4 $\mathrm{h}$ at $103 \pm 2{ }^{\circ} \mathrm{C}$ ). They were then extracted in the Soxhlet apparatus (Sigma-Aldrich, Munich, Germany) using ethanol-toluene solution $(1.0 / 0.427 \mathrm{v} / \mathrm{v})$. Cellulose and holocellulose were obtained according to the procedures described in [4]. Dioxane lignin was isolated from each sample (10 $\mathrm{g}$ from $200 \mathrm{~mL}$ of dioxane-water mixture for $5 \mathrm{~h}$ at $80^{\circ} \mathrm{C}$ ) according to the procedures presented in [16]. Samples of cellulose, holocellulose and dioxane lignin were further analyzed by attenuated total reflectance (ATR)-FTIR and SEC techniques. The methods used to prepare and isolate the main wood components ensure their minimal contamination by substances from other wood components and can be considered clean and suitable for analysis.

\subsection{ATR-FTIR Analysis}

FTIR spectra of isolated main wood components were recorded on a Nicolet iS10 FT-IR spectrometer (Thermo Fisher Scientific, Waltham, MA, USA), equipped with Smart iTR using an attenuated total 
reflectance (ATR) sampling accessory attached to a diamond crystal. Initially, background measurement was performed to subtract it from the resulting spectrum. The spectra were acquired by accumulating 64 scans at a spectral resolution of $4 \mathrm{~cm}^{-1}$ in an absorbance mode from 4000 to $650 \mathrm{~cm}^{-1}$ and standardised using the baseline method. Obtained data were analyzed using the OMNIC 8.0 software. Measurements were performed four times per sample.

\subsection{Size-Exclusion Chromatography}

The molecular weight distribution (MWD) of lignin was measured with Agilent 1200 HPLC chromatograph (Agilent Technologies, Santa Clara, CA, USA) by previously described SEC method [16]. The isolated dioxane lignin was dissolved in dimethyformamide (DMF) ( $\left.\mathrm{c}=5 \mathrm{mg} \cdot \mathrm{mL}^{-1}\right)$ and filtered through a Puradisc 25 NYL filter (Whatman International, Maidstone, UK) with a pore size of $0.45 \mu \mathrm{m}$. The separation was performed at $35^{\circ} \mathrm{C}$ with $\mathrm{LiBr}(0.005 \mathrm{M})$ in DMF at a flow rate of $1 \mathrm{~mL} \cdot \mathrm{min}^{-1}$ on a POLAR-M column $(7.5 \mathrm{~mm} \times 300 \mathrm{~mm}$, Agilent Technologies, Santa Clara, CA, USA). A differential refractometer (RI) and diode array detector (DAD) at $280 \mathrm{~nm}$ were used as the detectors. Data were acquired with Chemstation software (Agilent) and analyzed with the Clarity GPC module. The system was calibrated with polystyrene standards from 500 to $98,900 \mathrm{~g} \cdot \mathrm{mol}^{-1}$. All SEC results represent the mean of two different samples and each sample was run in two replicates.

Samples of cellulose and holocellulose were derivatized using phenyl isocyanate to obtain tricarbanilates which were dissolved in tetrahydrofuran prior to the size exclusion chromatography (SEC) analysis. The derivatives were prepared according to procedure described previously [17]. SEC analyses were performed at $35{ }^{\circ} \mathrm{C}$ with tetrahydrofuran at a flow rate of $1 \mathrm{~mL} \cdot \mathrm{min}^{-1}$ on a two PLgel, $10 \mu \mathrm{m}, 7.5 \times 300 \mathrm{~mm}$, MIXED B columns preceded by a PLgel, $10 \mu \mathrm{m}, 7.5 \times 50 \mathrm{~mm}$, GUARD column (Agilent Technologies, Santa Clara, CA, USA). Two tricarbanilate derivatives were prepared for each sample and each derivative was analyzed twice.

\section{Results and Discussion}

\subsection{Changes in the FTIR Spectra}

As it is well known, the absorption bands characteristic of lignin, cellulose and hemicelluloses lie in the wavelength range from 1800 to $800 \mathrm{~cm}^{-1}$ (stretching and bending vibrations within the molecules, also called as the fingerprint region). In addition, an area between 3550 and $2900 \mathrm{~cm}^{-1}$ $(\mathrm{OH}$ and $\mathrm{C}-\mathrm{H}$ stretching) is also important for the main wood components.

\subsubsection{FTIR Spectra of Lignin Isolated from Heat Treated Samples}

The major lignin bands in lignin structure are approximately at 1596, 1510, 1464, 1423, 1367, 1326, 1269 and $1221 \mathrm{~cm}^{-1}$ [18]. Cheng et al. [19] investigated identifying changes in the main components of wood after thermal treatment, focusing on selected bands ranging from 1730 to $1110 \mathrm{~cm}^{-1}$. In addition, lignin can also be assigned a broad region including an interval $3300-3600 \mathrm{~cm}^{-1}$ (intramolecular hydrogen bond in phenolic groups, $\mathrm{OH}$ stretching of alcohols, phenols, acids and weakly bounded absorbed water) and bands about $2900 \mathrm{~cm}^{-1}$ (C-H stretching in methyl and methylene groups) [20-22]. The following changes indicate the thermal degradation of lignin that was isolated from the heat-treated oak samples.

In our case, at the $3420 \mathrm{~cm}^{-1}$ region only small changes with a slight decreasing of band intensities were observed (on samples "180" and "210", Figure 1). Other researchers found a decrease in the amount of $\mathrm{OH}$ groups in the heat-treated wood too, probably due to condensation reactions [21,23]. The shift to lower wavelengths and mild widening of the band is also observable, which can be caused by oxidation and hydrolysis of acetyl groups from hemicelluloses [21] or crosslinking of free hydroxyl groups [24]. A similar trend was also seen in the $2940 \mathrm{~cm}^{-1}$ (asymmetric $\mathrm{CH}_{2}$ stretching) and $2840 \mathrm{~cm}^{-1}$ (symmetric $\mathrm{CH}_{2}$ stretching) band region (Figure 1). That trend might be due to structural and relative composition changes, namely, changes at the cellulose crystallinity level [25]. 
The absorption in FTIR spectra including an interval between 1750 and $1700 \mathrm{~cm}^{-1}(\mathrm{C}=\mathrm{O}$ stretching in unconjugated groups) reflects changes in various functional groups in lignin and hemicelluloses (carbonyls, ester groups, ketones, aldehydes, carboxylic acids) [21,26]. Our measurements showed an increase in absorbance on the $1723 \mathrm{~cm}^{-1}$ band (Figure 1). Its value copied the increase in temperature used in the heat treatment and band shifted to lower wavenumbers (from 1723 to $1708 \mathrm{~cm}^{-1}$ ). This shift may be due to conjugation of the carbonyl group to other double bonds (aromatics, alkenes) supported by an increase in carbonyl or carboxyl groups due to oxidation reactions as a result of the temperature increase in the thermal degradation process [21]. Li et al. 2002 [27] studied the heat degradation of lignin in hardwood and softwood and obtained an increase in the band at $1720 \mathrm{~cm}^{-1}$ with increasing temperature, which they concluded to be due to the production of $\mathrm{C}=\mathrm{O}$ bonds in lignin. Increasing of intensity may be due to more pronounced cleavage of the $\beta$-alkyl-aryl ether bonds and the production of $\mathrm{C}=\mathrm{O}$ bonds within the lignin [21,28]. Increasing the amount of acetyl groups and carboxylic acid groups from lignin and saccharides may also be the cause of absorbance growth [21,28]. The cause of these changes is the splitting of aliphatic side chains in lignin and cleavage of $\beta-\mathrm{O}-4$ linkages, during thermal treatment $[29,30]$.

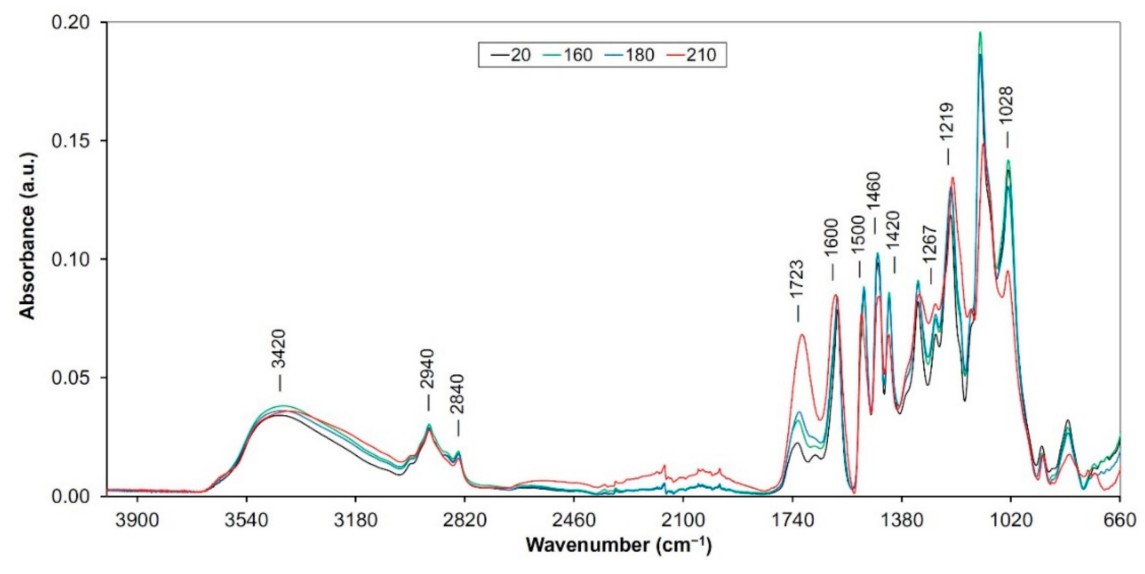

Figure 1. FTIR spectra of the thermally treated lignin from oak wood.

The band near $1600 \mathrm{~cm}^{-1}$ ( $\mathrm{C}=\mathrm{C}$ stretching of the aromatic ring in lignin) is related to unsaturated linkages and aromatic rings present in lignin [31]. With increasing temperature initially, it slightly increases (but then shows only minor changes, Figure 1). The changes in this area are related to lignin condensation at the expense of conjugated carbonyl groups and to the carboxylation of polysaccharides [32].

The band at $1500 \mathrm{~cm}^{-1}$ ( $\mathrm{C}=\mathrm{C}$ aromatic skeletal vibrations stretching of the benzene ring in lignin) shows a weak decrease with increase of treatment temperature and shift to $1512 \mathrm{~cm}^{-1}$ (Figure 1). This band is associated with guaiacyl and syringyl units in wood lignin. A decrease in absorbance at higher temperature is due to the decrease of methoxyl groups, the loss of syringyl units or breaking of aliphatic side-chains [21]. Several authors reported the increase of absorbance around $1505 \mathrm{~cm}^{-1}$ in thermally treated beech, teak and oak wood [33]. Demethoxylation at thermal treatment is supported by the shifting of maximum absorption from $1505 \mathrm{~cm}^{-1}$ to $1512 \mathrm{~cm}^{-1}[34,35]$. This trend was also observed by other authors [36,37].

At bands of $1460 \mathrm{~cm}^{-1}$ (asymmetric C-H deformations in lignin) and $1420 \mathrm{~cm}^{-1}$ (aromatic skeletal vibration in lignin with $\mathrm{C}-\mathrm{H}$ deformation and carbohydrates) a slight decrease was noted (most sharply at $210^{\circ} \mathrm{C}$, Figure 1 ). These changes were caused by lignin degradation and the cleavage of methoxyl groups during heat treatment [16]. During the thermal treatment of lignin, there occurs elimination of water and methanol to give the conjugated ethylenic bonds [38]. The bands at $1267 \mathrm{~cm}^{-1}$ (C-O stretching of guaiacyl ring) [18] and at $1219 \mathrm{~cm}^{-1}$ (C-O stretching of syringyl ring) after an initial increase, they decrease slightly on all samples (Figure 1). However, the decrease in absorbent band intensity corresponding to the guaiacyl structure is milder than that of syringyl. The observed course confirms the assumption that the degradation of the syringyl units occurs at a lower temperature than 
guaiacyl [30]. According to [39,40], the bands are in the 1190 to $950 \mathrm{~cm}^{-1}$ area attributed to the C-O and $\mathrm{C}-\mathrm{H}$ vibrations that are derived from aliphatic $-\mathrm{CH}_{2}$ or phenol $-\mathrm{OH}$ bonds. The slight decrease of absorbance at this region indicated gradual degradation of methyl and hydroxyl groups [2]. In our case the band at $1028 \mathrm{~cm}^{-1}$ (methoxyl groups in lignin) [41] decreased permanently (Figure 1). This trend is attributable to the partial demethoxylation of lignin and its gradual crosslinking [28].

\subsubsection{FTIR Spectra of Holocellulose Complex Isolated from Heat Treated Samples}

The holocellulose (hemicelluloses + cellulose) degraded at the thermal treatment. Similarly, to the isolated dioxane lignin, there are striking bands around the carbohydrate complex around of $3300 \mathrm{~cm}^{-1}, 2890 \mathrm{~cm}^{-1}$ and the band within the range of 1740 to $1725 \mathrm{~cm}^{-1}$. Bands at 3338 and $2897 \mathrm{~cm}^{-1}$ were increased with thermal modification process (Figure 2). This effect may be due to oxidation and hydrolysis of acetyl groups from hemicelluloses [21].

Band at $1732 \mathrm{~cm}^{-1}$ (Figure 2) is attributed to unconjugated carbonyl stretching in hemicelluloses (C-O stretching vibration in acetyl, carbonyl and carboxyl groups) [42]. Continual decreases in the signal intensities were observed together with an increase of treated temperature on all samples (Figure 2). This suggests that cleavage of acetyl side chains in hemicellulose occurred [43]. The decrease in absorbance around $1740 \mathrm{~cm}^{-1}$ could be due to reduced hemicellulose content in the heat-treated wood. Similar results were also obtained by $[10,44]$ on heat-treated samples. Özgenç et al. 2017 [30] discovered that thermal treatment of wood induced the degradation of hemicellulose. Band at $1633 \mathrm{~cm}^{-1}$ (conjugated $\mathrm{C}-\mathrm{O}$ in quinones coupled with $\mathrm{C}=\mathrm{O}$ stretching in various groups) $[32,43]$ shows a fluent though slight decrease under the thermal treatment (Figure 2). This trend may point to the cleavage of the $\alpha$-alkyl-aryl ether bonds [16]. Absorbance at $1600 \mathrm{~cm}^{-1}$ and around of $1500 \mathrm{~cm}^{-1}$ have a minimal value and continually decreases, confirming the negligible content of benzene nuclei in isolated holocellulose (Figure 2). The bands around of $1427 \mathrm{~cm}^{-1}$ did not show any significant changes in the heat-treated samples (except the sample "210", Figure 2). Absorption band at $1371 \mathrm{~cm}^{-1}$ $\left(\mathrm{CH}_{2}\right.$ bending in cellulose and hemicelluloses) rose slightly at all samples (but most significantly at the sample treated at $210^{\circ} \mathrm{C}$, Figure 2). We found an increase of intensity around the $1318 \mathrm{~cm}^{-1}$ (Figure 2). According to $[45,46]$, the higher intensity confirms an increase of condensed structures.

The band at $1241 \mathrm{~cm}^{-1}$ (C-O stretching vibration in xyloglucan) indicated a permanent decrease (Figure 2) in the height which again confirms the existence of more condensed structures [46]. Band at $1161 \mathrm{~cm}^{-1}$ (C-O-C vibrations in cellulose and hemicelluloses) [47] shows a slight increase, especially at $210{ }^{\circ} \mathrm{C}$, (Figure 2). This behavior suggests dehydration reactions forming covalent intermolecular bonds, i.e., cross-links, by ether bonds and gradual decomposition of carbohydrates $[25,48]$.

Bands at $1030 \mathrm{~cm}^{-1}$ (C-O-C stretching of primary alcohol in cellulose and hemicelluloses) $[45,49]$ and $897 \mathrm{~cm}^{-1}\left(\mathrm{C}_{1}-\mathrm{H}\right.$ deformation of glucose ring in cellulose and hemicellulose) $[31,50]$ increased continuously (Figure 2). It confirms gradual changes in the cellulose structure.

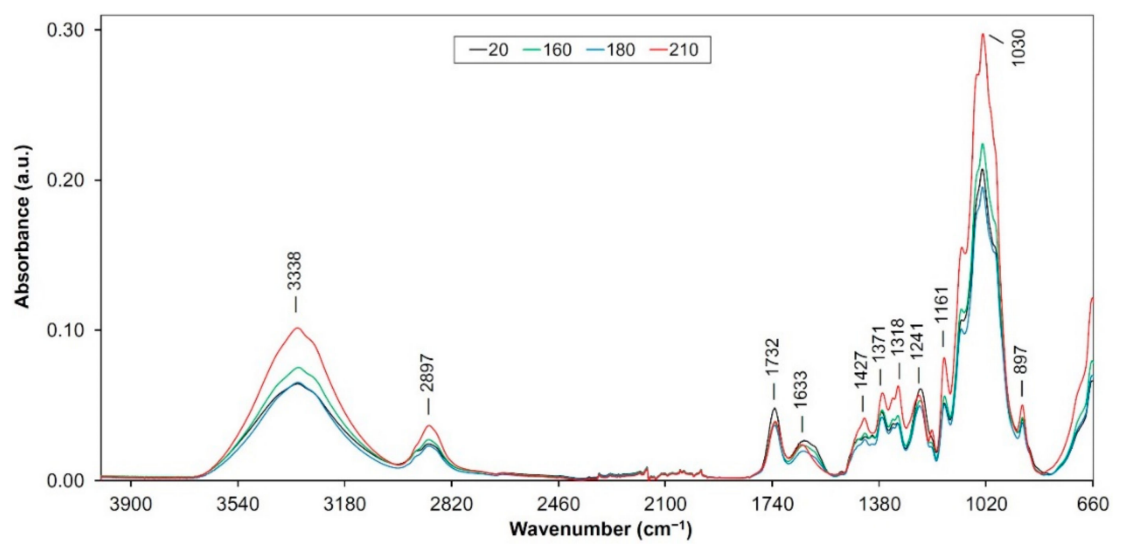

Figure 2. FTIR spectra of the thermally treated holocellulose from oak wood. 


\subsubsection{FTIR Spectra of Cellulose Isolated from Heat Treated Samples}

At the beginning it is necessary to consider the fact that in the method used, cellulose is not obtained in a pure state but only as a preparation with a small portion of lignin and hemicelluloses. FTIR spectra of cellulose are slightly perturbed by bands derived from lignin and hemicellulose. Band around $3336 \mathrm{~cm}^{-1}$ (intramolecular hydrogen bonds in cellulose) shows a gradual decrease in absorbance, where the highest decline shows at the samples modified at maximum temperature (Figure 3). This may be due to the lower content of hydroxyl groups in both holocellulose and lignin as a result of the process used to isolate cellulose from heat treated wood samples. At the band of $2894 \mathrm{~cm}^{-1}$ (C-H stretching in methylene groups), it was observed that the absorbance value decreases slowly (Figure 3). The cause of the decrease in absorbance may be cellulose degradation and an increase in its crystalline fraction [25].

The absorption bands of 1726 and $1643 \mathrm{~cm}^{-1}$ have a minimum height in the FTIR spectrum of isolated cellulose from thermally modified wood (Figure 3). These bands are associated with the hemicellulose complex, and their decline suggests decomposition of the carbohydrate components that have remained in the extraction of cellulose from the original wood samples.

The band around of $1429 \mathrm{~cm}^{-1}$ (C-H vibration in plane cellulose) [51] show small increase in absorbance with an increase of temperature (especially at " 210 " sample, Figure 3). It can be a confirmation of the increase in the amount of the crystalline cellulose. Absorption band at $1368 \mathrm{~cm}^{-1}$ $\left(\mathrm{CH}_{2}\right.$ bending in cellulose and hemicelluloses), identically to the band at $1318 \mathrm{~cm}^{-1}$ decreased slightly, which confirms degradation of hemicelluloses (Figure 3). Conversely, the absorption of the band at $1259 \mathrm{~cm}^{-1}$ increased slightly, which may be due to residual lignin contained in the isolated cellulose. Intensity at $1160 \mathrm{~cm}^{-1}$ (C-O-C vibrations in cellulose) as well as $1030 \mathrm{~cm}^{-1}$ (associated with cellulose deformations) decreased gradually (Figure 3), probably due to beginning of cellulose degradation processes.

The band at $897 \mathrm{~cm}^{-1}$ which is specific to glucose ring stretching vibration decreased slightly with an increase of treatment temperature (Figure 3). It may be due to thermal degradation of $\beta-(1,4)$ glycosidic bonds [37]. Decreasing the absorption at this band indicates a decrement of the amorphous form of cellulose [52].

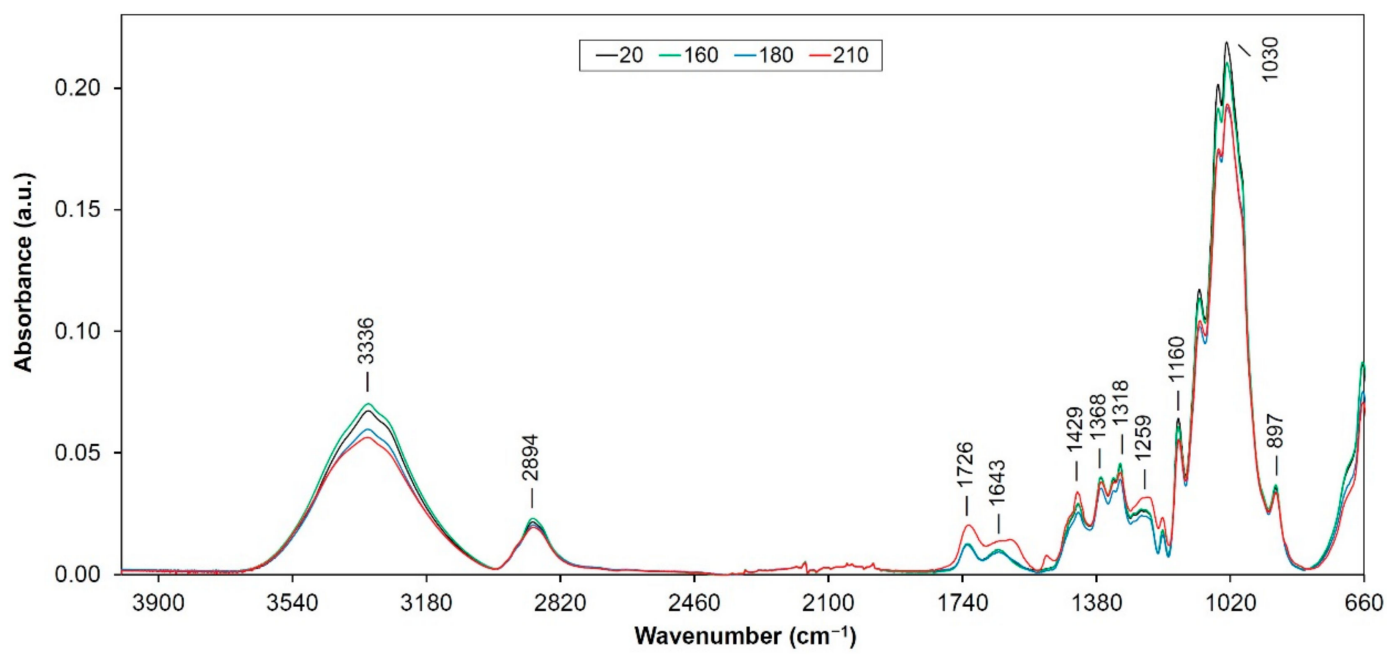

Figure 3. FTIR spectra of the thermally treated cellulose from oak wood.

\subsection{Changes of Macromolecular Traits in Lignin and Polysaccharides}

Lignin is one of the less thermally stable polymers, and its relative content increases after thermal treatment $[53,54]$. However, structural changes in the lignin during the modification, such as cleavage of the methoxyl groups and depolymerization of the lignin macromolecule to lower molecular weight compounds and subsequent re-polymerization. SEC analyses indicate (Table 1, Figure 4) a slight 
decrease of lignin molecular weight up to temperature of $180{ }^{\circ} \mathrm{C}$, followed by its increase. The drop of molecular weight is due to cleavage of the different $\mathrm{C}-\mathrm{O}$ bonds of $\mathrm{C} 3$ side chain and especially of $\beta-\mathrm{O}-4$ ether linkage [5]. Simultaneously, reactive intermediate species like carbonium ions, which can be formed during cleavage of benzylic $\mathrm{C}-\mathrm{O}$ bond, are involved in recondensation reactions [55].

The predominance of degradation and condensation reactions depends mostly on the temperature and the duration of the thermal treatment. At lower temperatures and/or at shorter modification, degradation reactions predominate. Higher temperatures and/or prolonged treatment cause mainly condensation reactions and molecular weight increases [56,57]. Our findings confirmed that depolymerization, side chain cleavage and recondensation occur during the exposure to heat $[13,58]$.

Table 1. Size exclusion chromatography (SEC) results of oak wood lignin before and after thermal treatment ${ }^{\mathrm{a}, \mathrm{b}}$.

\begin{tabular}{cccccc}
\hline $\boldsymbol{T}\left({ }^{\circ} \mathbf{C}\right)$ & $\boldsymbol{M}_{\mathbf{n}}$ & $\boldsymbol{M}_{\mathbf{w}}$ & $\boldsymbol{M}_{\mathbf{z}}$ & $\boldsymbol{M}_{\mathbf{z}+\mathbf{1}}$ & PDI \\
\hline \multirow{2}{*}{20} & 3474 & 9216 & 23,004 & 47,401 & 2.65 \\
& $(19)$ & $(138)$ & $(672)$ & $(1786)$ & $(0.03)$ \\
\hline \multirow{2}{*}{160} & 2987 & 8477 & 23,838 & 54,001 & 2.84 \\
& $(34)$ & $(22)$ & $(97)$ & $(310)$ & $(0.03)$ \\
\hline \multirow{2}{*}{180} & 2736 & 7650 & 24,899 & 63,155 & 2.80 \\
& $(23)$ & $(24)$ & $(644)$ & $(1626)$ & $(0.03)$ \\
\multirow{2}{*}{210} & 3021 & 8435 & 21,517 & 44,751 & 2.79 \\
& $(46)$ & $(20)$ & $(268)$ & $(1075)$ & $(0.05)$ \\
\hline
\end{tabular}

a Standard deviation values are in parentheses. ${ }^{\mathrm{b}} M_{\mathrm{n}}=$ number average molecular weight $(\mathrm{MW}), M_{\mathrm{w}}=$ weight-average MW, $M_{\mathrm{z}}=\mathbf{z}$ average MW, $M_{\mathrm{z}+1}=\mathrm{z}+1$ average MW, PDI (polydispersity index) $=M_{\mathrm{w}} / M_{\mathrm{n}}$.

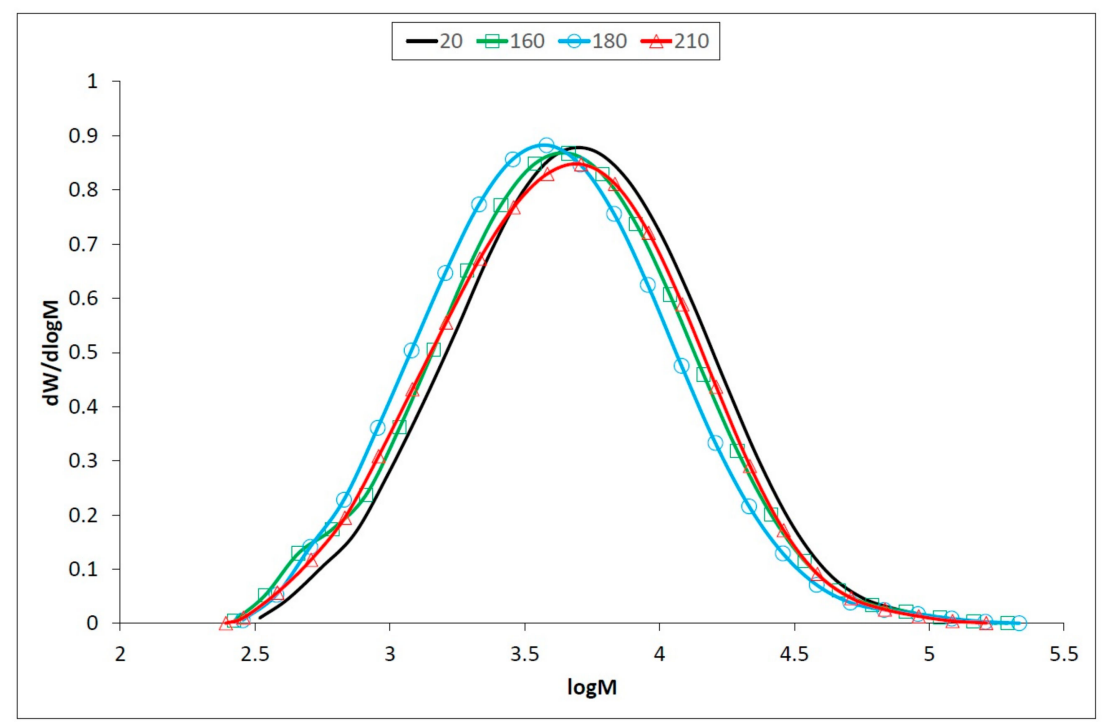

Figure 4. Molecular weight distribution of oak wood lignin before and after thermal treatment.

In holocellulose samples, a significant drop in degree of polymerization (DP) occur at $160{ }^{\circ} \mathrm{C}$, by the simultaneous splitting of longer chains of cellulose to shorter hemicelluloses-like chains (Table 2 , Figure 5). However, hemicelluloses degraded more rapidly, and the decrease of non-glucose saccharides was observed in thermally treated oak wood [4]. This process is more evident at the temperature of $180^{\circ} \mathrm{C}$ leading to a decrease of DP and an increase of polydispersity. In addition to the cleavage of the polysaccharide chains, crosslinking reactions take place at $210^{\circ} \mathrm{C}$, with DP and polydispersity increases (Table 2). A similar phenomenon was observed in the accelerated aging of newsprint paper, which contained about $12 \%$ hemicelluloses [17]. Crosslinking in thermally degraded celluloses can take two forms: hydrogen bonding between adjacent chains, or the formation of covalent bridges which join 
chains together. The effects of crosslinking, particularly covalent crosslinking is to counteract the drop in DP arising from chain scission through network formation [59].

Table 2. SEC results of oak wood holocellulose before and after thermal treatment ${ }^{\mathrm{a}, \mathrm{b}}$.

\begin{tabular}{ccccccc}
\hline $\boldsymbol{T}\left({ }^{\circ} \mathbf{C}\right)$ & $\boldsymbol{M}_{\mathbf{n}}$ & $\boldsymbol{M}_{\mathbf{w}}$ & $\boldsymbol{M}_{\mathbf{z}}$ & $\boldsymbol{M}_{\mathbf{z}+\mathbf{1}}$ & PDI & DP \\
\hline \multirow{2}{*}{20} & 51,097 & 212,995 & 461,299 & 699,959 & 4.17 & 1315 \\
& $(542)$ & $(8405)$ & $(33,735)$ & $(65,649)$ & $(0.18)$ & $(52)$ \\
\hline \multirow{2}{*}{160} & 44,400 & 186,382 & 487,413 & 817,872 & 4.20 & 1151 \\
& $(577)$ & $(3793)$ & $(13,473)$ & $(33,397)$ & $(0.09)$ & $(23)$ \\
\hline \multirow{2}{*}{180} & 27,524 & 146,648 & 640,517 & $1,339,376$ & 5.33 & 905 \\
& $(353)$ & $(8298)$ & $(33,698)$ & $(61,086)$ & $(0.25)$ & $(51)$ \\
\hline \multirow{2}{*}{210} & 29,042 & 275,447 & $1,223,920$ & $1,929,683$ & 9.48 & 1700 \\
& $(327)$ & $(12,292)$ & $(28,533)$ & $(24,264)$ & $(0.35)$ & $(76)$ \\
\hline
\end{tabular}

a Standard deviation values are in parentheses. ${ }^{\mathrm{b}} M_{\mathrm{n}}=$ number average molecular weight $(\mathrm{MW}), M_{\mathrm{w}}=$ weight-average MW, $M_{\mathrm{z}}=\mathbf{z}$ average MW, $M_{\mathrm{z}+1}=\mathrm{z}+1$ average MW, PDI (polydispersity index) $=M_{\mathrm{w}} / M_{\mathrm{n}}$, DP $=$ degree of polymerization.

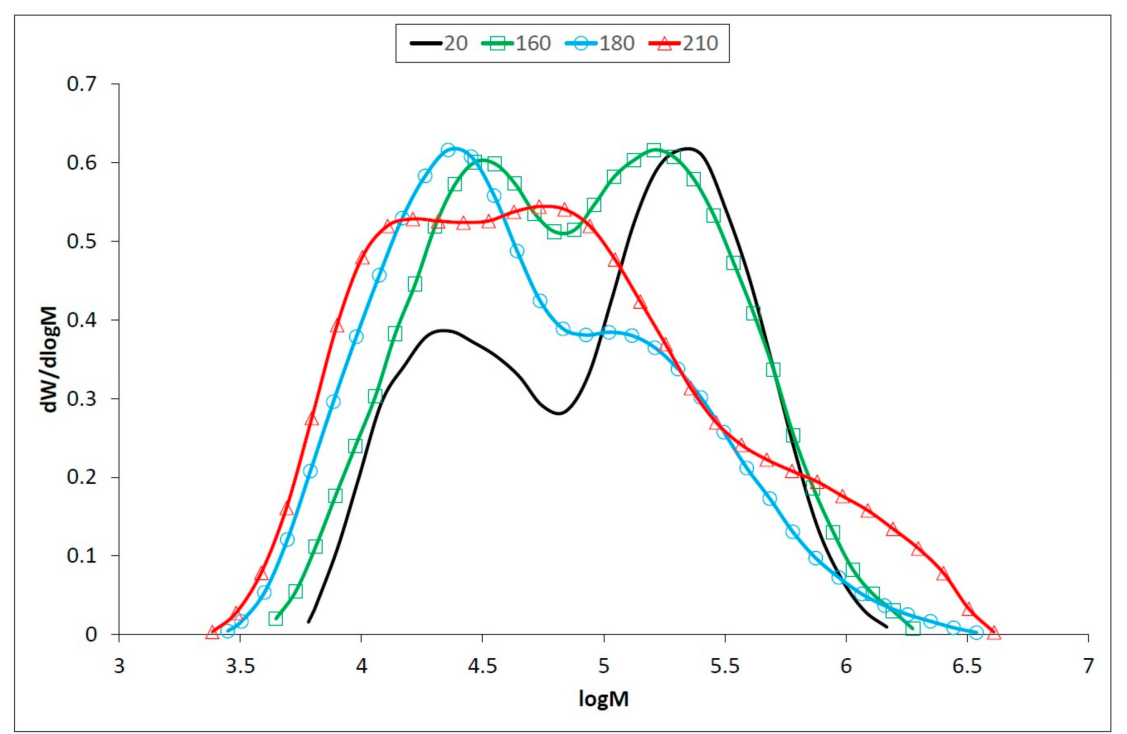

Figure 5. Molecular weight distribution of oak wood holocellulose before and after thermal treatment.

Apart from cellulose, where DP decreases at the temperature of $210{ }^{\circ} \mathrm{C}$, DP in holocellulose increases up to DP approx. 1700 (Table 2, Figure 5).

Cellulose is relatively stable to thermal treatment. However, minor degradation occurs at relatively low temperatures [60], but it is not as strongly affected as the hemicelluloses. The results of SEC analyses (Table 3, Figure 6) show that the temperature of $160^{\circ} \mathrm{C}$ affects the length of the cellulose chain only slightly and the changes in degree of polymerization (DP) are not significant. At $180^{\circ} \mathrm{C}$, the high molecular weight cellulose fractions cleave, and the proportion of low molecular weight fractions increases. This effect continues at $210{ }^{\circ} \mathrm{C}$, whereby low-molecular chains are also cleaved, and DP is $20 \%$ lower than for untreated samples [61]. At elevated temperatures, an important amount of acetic acid is released via deacetylation of hemicelluloses which catalyzes depolymerization of the less ordered carbohydrates as hemicelluloses and amorphous cellulose $[62,63]$. This causes a decrease of DP and an increase of crystallinity. 
Table 3. SEC results of oak wood cellulose before and after thermal treatment ${ }^{a, b}$.

\begin{tabular}{ccccccc}
\hline $\boldsymbol{T}\left({ }^{\circ} \mathbf{C}\right)$ & $\boldsymbol{M}_{\mathbf{n}}$ & $\boldsymbol{M}_{\mathbf{w}}$ & $\boldsymbol{M}_{\mathbf{z}}$ & $\boldsymbol{M}_{\mathbf{z}+\mathbf{1}}$ & PDI & DP \\
\hline \multirow{2}{*}{20} & 39,375 & 385,896 & $1,150,316$ & $1,808,690$ & 9.81 & 2382 \\
& $(1165)$ & $(2376)$ & $(14,034)$ & $(26,230)$ & $(0.31)$ & $(15)$ \\
\hline \multirow{2}{*}{160} & 35,634 & 384,908 & $1,130,145$ & $1,758,540$ & 10.80 & 2376 \\
& $(438)$ & $(607)$ & $(4320)$ & $(18,341)$ & $(0.14)$ & $(4)$ \\
\hline \multirow{2}{*}{180} & 30,154 & 355,894 & $1,190,572$ & $1,907,652$ & 11.80 & 2197 \\
& $(226)$ & $(1091)$ & $(4984)$ & $(8892)$ & $(0.10)$ & $(7)$ \\
\hline \multirow{2}{*}{210} & 33,560 & 306,850 & $1,044,946$ & $1,728,619$ & 9.14 & 1894 \\
& $(232)$ & $(2385)$ & $(10,935)$ & $(19,617)$ & $(0.13)$ & $(15)$ \\
\hline
\end{tabular}

a Standard deviation values are in parentheses. ${ }^{\mathrm{b}} M_{\mathrm{n}}=$ number average molecular weight $(\mathrm{MW}), M_{\mathrm{W}}=$ weight-average MW, $M_{z}=\mathbf{z}$ average MW, $M_{z+1}=\mathrm{z}+1$ average MW, PDI (polydispersity index) $=M_{\mathrm{w}} / M_{\mathrm{n}}$, DP $=$ degree of polymerization.

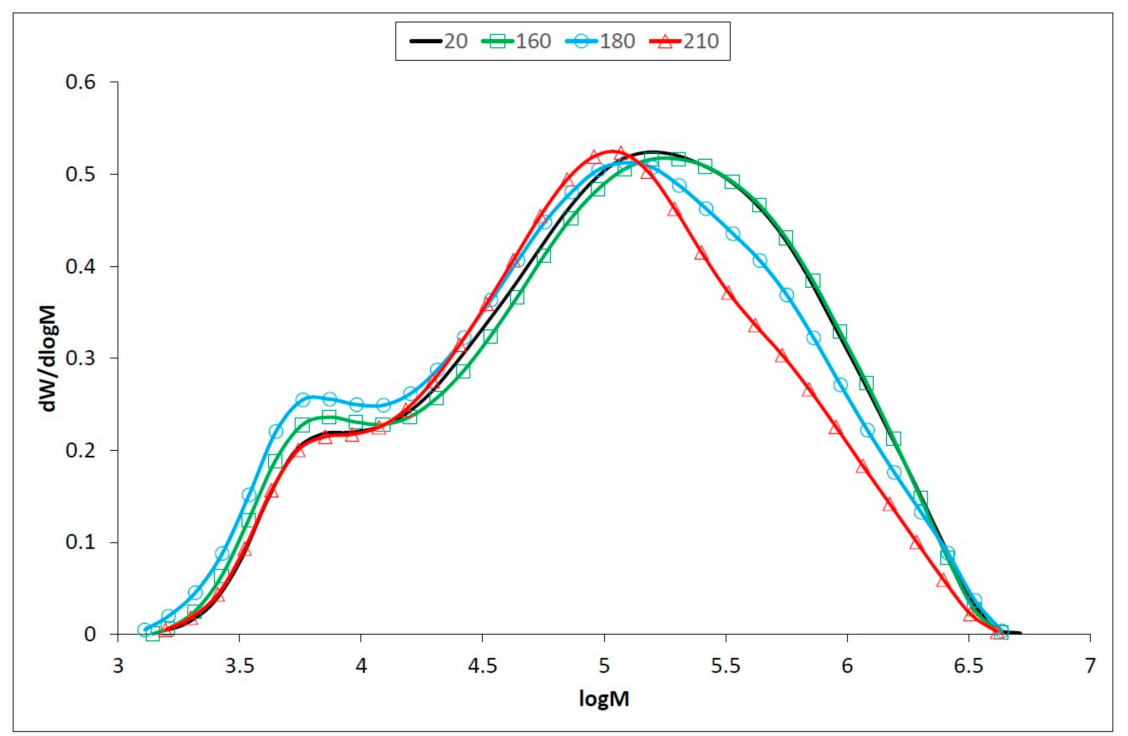

Figure 6. Molecular weight distribution of oak wood cellulose before and after thermal treatment.

\section{Conclusions}

The influence of the thermal modification on the chemical changes of oak wood polysaccharides was investigated. Based on Fourier transform infrared spectroscopy and size exclusion chromatography, it can be concluded that thermal treatment leads to an increase of carbonyl groups in lignin together with splitting of aliphatic side chains and demethoxylation.

The predominance of lignin degradation is evident at lower temperatures, higher temperatures cause mostly condensation reactions and molecular weight increases. Degradation of hemicelluloses resulted in deacetylation and released acetic acid catalyzes hydrolysis of polysaccharide chains. This process is more evident at the temperature of $180^{\circ} \mathrm{C}$ leading to a decrease of molecular weight and increase of polydispersity. In addition to the cleavage of the polysaccharide chains, crosslinking reactions take place at $210^{\circ} \mathrm{C}$, with molecular weight and polydispersity increasing.

These structural changes in the main wood components have significant influences on various properties of thermally modified wood. Thermally treated wood is characterized by higher resistance to biotic pests and increases its dimensional and shape stability. According to some sources cited, the thermal modification leads to a reduction in the mechanical strength, which can cause a problem in wood structures damaged by fire. This knowledge should be considered when using thermally treated wood in the design of stressed timber structures. 
Author Contributions: I.K. and F.K. conceived and designed the experiments; F.K. and D.K. prepared samples of isolated wood polymers; I.K. measured and analyzed FTIR spectra; F.K. measured and analyzed molecular weight distribution by SEC method; D.K. and F.K. calculated dependencies from obtained data; I.K., F.K. and D.K. wrote the paper. All authors have read and agreed to the published version of the manuscript.

Funding: This work was supported by the Slovak Research and Development Agency under the contracts No. APVV-17-0005 (25\%) and No. APVV-16-0326 (25\%), and by the VEGA Agency of Ministry of Education, Science, Research and Sport of the Slovak Republic No. 1/0493/18 (25\%) and No. 1/0387/18 (25\%).

Conflicts of Interest: The authors declare no conflict of interest. The funders had no role in the design of the study; in the collection, analyses, or interpretation of data; in the writing of the manuscript, and in the decision to publish the results.

\section{References}

1. Priadi, T.; Hiziroglu, S. Characterization of heat treated wood species. Mater. Des. 2013, 49, 575-582. [CrossRef]

2. Xu, J.; Zhang, Y.; Shen, Y.; Li, C.; Wang, Y.; Ma, Z.; Sun, W. New perspective on wood thermal modification: Relevance between the evolution of chemical structure and physical-mechanical properties, and online analysis of release of VOCs. Polymers 2019, 11, 1145. [CrossRef]

3. Okon, K.E.; Lin, F.; Chen, Y.; Huang, B. Effect of silicone oil heat treatment on the chemical composition, cellulose crystalline structure and contact angle of Chinese parasol wood. Carbohydr. Polym. 2017, 164, 179-185. [CrossRef]

4. Sikora, A.; Kačík, F.; Gaff, M.; Vondrová, V.; Bubeníková, T.; Kubovský, I. Impact of thermal modification on color and chemical changes of spruce and oak wood. J. Wood Sci. 2018, 64, 406-416. [CrossRef]

5. Gerardin, P. New alternatives for wood preservation based on thermal and chemical modification of wood-a review. Ann. Sci. 2016, 73, 559-570. [CrossRef]

6. Kubovský, I.; Oberhofnerová, E.; Kačík, F.; Pánek, M. Surface changes of selected hardwoods due to weather conditions. Forests 2018, 9, 557. [CrossRef]

7. Esteves, B.; Pereira, H. Wood modification by heat treatment: A review. BioResources 2009, 4, 370-404.

8. Turner, I.; Rousset, P.; Rémond, R.; Perré, P. An experimental and theoretical investigation of the thermal treatment of wood (Fagus sylvatica L.) in the range 200-260 ${ }^{\circ}$ C. Int. J. Heat Mass Transf. 2010, 53, 715-725. [CrossRef]

9. Kačíková, D.; Kačík, F.; Čabalová, I.; Ďurkovič, J. Effects of thermal treatment on chemical, mechanical and colour traits in Norway spruce wood. Bioresour. Technol. 2013, 144, 669-674. [CrossRef]

10. Nuopponen, M.; Vuorinen, T.; Jamsä, S.; Viitaniemi, P. Thermal modifications in softwood studied by FT-IR and UV resonance Raman spectroscopies. J. Wood Chem. Technol. 2004, 24, 13-26. [CrossRef]

11. Wikberg, H.; Maunu, S.L. Characterization of thermally modified hard and softwoods by 13C CPMAS NMR. Carbohyd. Polym. 2004, 58, 461-466. [CrossRef]

12. Yildiz, S.; Gümüskaya, E. The effects of thermal modification on crystalline structure of cellulose in soft and hardwood. Build. Environ. 2007, 42, 62-67. [CrossRef]

13. Kocaefe, D.; Poncsak, S.; Boluk, Y. Effect of thermal treatment on the chemical composition and mechanical properties of birch and aspen. BioResources 2008, 3, 517-537. [CrossRef]

14. Gaff, M.; Kačík, F.; Sandberg, D.; Babiak, M.; Turčáni, M.; Niemz, P.; Hanzlík, P. The effect of chemical changes during thermal modification of European oak and Norway spruce on elasticity properties. Compos. Struct. 2019, 220, 529-538. [CrossRef]

15. Gaff, M.; Babiak, M.; Kačík, F.; Sandberg, D.; Turčáni, M.; Hanzlík, P.; Vondrová, V. Plasticity properties of thermally modified timber in bending-The effect of chemical changes during modification of European oak and Norway spruce. Compos. Part B Eng. 2019, 165, 613-625. [CrossRef]

16. Kačík, F.; Luptáková, J.; Šmíra, P.; Nasswettrová, A.; Kačíková, D.; Vacek, V. Chemical alterations of pine wood lignin during heat sterilization. BioResources 2016, 11, 3442-3452. [CrossRef]

17. Kačík, F.; Kačíková, D.; Jablonský, M.; Katuščák, S. Cellulose degradation in newsprint paper ageing. Polym. Degrad. Stabil. 2009, 94, 1509-1514. [CrossRef]

18. Faix, O. Classification of lignins from different botanical origins by FTIR spectroscopy. Holzforschung 1991, 45, 21-27. [CrossRef] 
19. Cheng, S.; Huang, A.; Wang, S.; Zhang, Q. Effect of Different Heat Treatment Temperatures on the Chemical Composition and Structure of Chinese Fir Wood. BioResources 2016, 11, 4006-4016. [CrossRef]

20. Shen, D.K.; Gu, S. The mechanism for thermal decomposition of cellulose and its main products. Bioresour. Technol. 2009, 100, 6496-6504. [CrossRef]

21. Esteves, B.; Marques, A.V.; Domingos, I.; Pereira, H. Chemical changes of heat treated pine and eucalypt wood monitored by FTIR. Maderas Cienc. Tecnol. 2013, 15, 245-258. [CrossRef]

22. Mattos, B.D.; Lourençon, T.V.; Serrano, L.; Labidi, J.; Gatto, D.A. Chemical modification of fast-growing eucalyptus wood. Wood Sci. Technol. 2015, 2, 273-288. [CrossRef]

23. Missio, A.L.; Mattos, B.D.; de Cademartori, P.H.; Pertuzzatti, A.; Conte, B.; Gatto, D.A. Thermochemical and physical properties of two fast-growing eucalypt woods subjected to two-step freeze-heat treatments. Acta 2015, 615, 15-22. [CrossRef]

24. Inari, G.N.; Petrissans, M.; Gerardin, P. Chemical reactivity of heat-treated wood. Wood Sci. Technol. 2007, 41, 157-168. [CrossRef]

25. Spiridon, I.; Teaca, C.A.; Bodǐrlău, R. Structural changes evidenced by FTIR spectroscopy in cellulosic materials after pretreatment with ionic liquid and enzymatic hydrolysis. BioResources 2011, 6, 400-413.

26. Ates, S.; Akyildiz, M.H.; Ozdemir, H. Effects of heat treatment on calabrian pine (Pinus brutia Ten.) wood. BioResources 2009, 4, 1032-1043. [CrossRef]

27. Li, J.; Li, B.; Zhang, X. Comparative studies of heat degradation between larch lignin and Manchurian ash lignin. Polym. Degrad. Stabil. 2002, 78, 279-285. [CrossRef]

28. Kačík, F.; Kačíková, D.; Bubeníková, T. Spruce wood lignin alteration after infrared heating at different wood moistures. Cell. Chem. Technol. 2006, 40, 643-648.

29. Vartanian, E.; Barres, O.; Roque, C. FTIR spectroscopy of woods: A new approach to study the weathering of the carving face of a sculpture. Spectrochim. Acta A 2015, 136, 1255-1259. [CrossRef]

30. Özgenç, Ö.; Durmaz, S.; Boyaci, I.H.; Eksi-Kocak, H. Determination of chemical changes in heat-treated wood using ATR-FTIR and FT Raman spectrometry. Spectrochim. Acta A 2017, 171, 395-400. [CrossRef]

31. Michell, A.; Higgins, H. Infrared Spectroscopy in Australian Forest Products Research; CSIRO Forestry and Forest Products: Melbourne, Australia, 2002; p. 60.

32. González-Peña, M.M.; Curling, S.F.; Hale, M.D. On the effect of heat on the chemical composition and dimensions of thermally-modified wood. Polym. Degrad. Stabil. 2009, 94, 2184-2193. [CrossRef]

33. Li, M.Y.; Cheng, S.C.; Li, D.; Wang, S.N.; Huang, A.M.; Sun, S.Q. Structural characterization of steam-heat treated Tectona grandis wood analyzed by FT-IR and 2D-IR correlation spectroscopy. Chin. Chem. Lett. 2015, 26, 221-225. [CrossRef]

34. Kubovský, I.; Kačík, F. Colour and chemical changes of the lime wood surface due to $\mathrm{CO}_{2}$ laser thermal modification. Appl. Surf. Sci. 2014, 321, 261-267. [CrossRef]

35. Wang, S.; Ru, B.; Dai, G.; Sun, W.; Qiu, K.; Zhou, J. Pyrolysis mechanism study of minimally damaged hemicellulose polymers isolated from agricultural waste straw samples. Bioresour. Technol. 2015, 190, 211-218. [CrossRef] [PubMed]

36. Colom, X.; Carrillo, F.; Nogués, F.; Garriga, P. Structural analysis of photodegraded wood by means of FTIR spectroscopy. Polym. Degrad. Stabil. 2003, 80, 543-549. [CrossRef]

37. Papp, G.; Barta, E.; Preklet, E.; Tolvaj, L.; Berkesi, O.; Nagy, T.; Szatmari, S. Changes in DRIFT spectra of wood irradiated by UV laser as a function of energy. J. Photochem. Photobio. A 2005, 173, 137-142. [CrossRef]

38. Bourgois, J.; Guyonnet, R. Characterization and analysis of torrefied wood. Wood Sci. Technol. 1988, 22, 143-155. [CrossRef]

39. Yang, H.; Rong, Y.; Chen, H.; Dong, H.L.; Zheng, C. Characteristics of hemicellulose, cellulose and lignin pyrolysis. Fuel 2007, 86, 1781-1788. [CrossRef]

40. Lin, B.J.; Colin, B.; Chen, W.H.; Pétrissans, A.; Rousset, P.; Pétrissans, M. Thermal degradation and compositional changes of wood treated in a semi-industrial scale reactor in vacuum. J. Anal. Appl. Pyrol. 2018, 130, 8-18. [CrossRef]

41. Collier, W.E.; Schultz, T.P.; Kalasinsky, V.F. Infrared Study of Lignin: Reexamination of Aryl-Alkyl Ether C-O Stretching Peak Assignments. Holzforschung 1992, 46, 523-528. [CrossRef]

42. Hosseinaei, O.; Wang, S.; Enayati, A.A.; Rials, T.G. Effects of hemicellulose extraction on properties of wood flour and wood-plastic composites. Compos. Part A Appl. Sci. 2012, 43, 686-694. [CrossRef] 
43. Popescu, M.C.; Froidevaux, J.; Navi, P.; Popescu, C.M. Structural modifications of Tilia cordata wood during heat treatment investigated by FT-IR and 2D IR correlation spectroscopy. J. Mol. Struct. 2013, 1033, 176-186. [CrossRef]

44. Miklečić, J.; Jirouš-Rajković, V.; Antonović, A.; Španić, N. Discolouration of thermally modified wood during simulated indoor sunlight exposure. BioResources 2011, 6, 434-446. [CrossRef]

45. Faix, O. Fourier transform infrared spectroscopy. In Methods in Lignin Chemistry; Lin, S.Y., Dence, C.W., Eds.; Springer: Berlin/Heidelberg, Germany, 1992; Chapter 4.1; pp. 83-109. [CrossRef]

46. Windeisen, E.; Strobel, C.; Wegener, G. Chemical changes during the production of thermo-treated beech wood. Wood Sci. Technol. 2007, 41, 523-536. [CrossRef]

47. Peng, W.; Wang, L.; Ohkoshi, M.; Zhang, M. Separation of hemicelluloses from Eucalyptus species: Investigating the residue after alkaline treatment. Cell. Chem. Technol. 2015, 49, 756-764.

48. Arif, S.; Kautek, W. Laser cleaning of particulates from paper: Comparison between sized ground wood cellulose and pure cellulose. Appl. Surf. Sci. 2013, 276, 53-61. [CrossRef]

49. Rodrigues, J.; Faix, O.; Pereira, H. Determination of lignin content of Eucalyptus globulus wood using FTIR spectroscopy. Holzforschung 1998, 52, 46-50. [CrossRef]

50. Fengel, D.; Ludwig, M. Möglichkeiten und Grenzen der FTIR-Spektroskopie bei der Charakterisierung von Cellulose. Teil 1. Vergleich von verschiedenen Cellulosefasern und Bakterien-Cellulose. Das Pap. 1991, 45, 45-51.

51. Kuo, M.L.; McClelland, J.F.; Luo, S.; Chien, P.L.; Walker, R.D.; Hse, C.Y. Applications of infrared photoacoustic spectroscopy for wood samples. Wood Fiber Sci. 1988, 20, 132-145.

52. Åkerholm, M.; Hinterstoisser, B.; Salmén, L. Characterization of the crystalline structure of cellulose using static and dynamic FT-IR spectroscopy. Carbohydr. Res. 2004, 339, 569-578. [CrossRef]

53. Alén, R.; Kotilainen, R.; Zaman, A. Thermochemical behavior of Norway spruce (Picea abies) at $180-225^{\circ} \mathrm{C}$. Wood Sci. Technol. 2002, 36, 163-171. [CrossRef]

54. Esteves, B.; Domingos, I.; Pereira, H. Pine wood modification by heat treatment in air. BioResources 2008, 3, 142-154. [CrossRef]

55. Weiland, J.J.; Guyonnet, R. Study of chemical modifications and fungi degradation of thermally modified wood using DRIFT spectroscopy. Holz Roh Werkst. 2003, 61, 216-220. [CrossRef]

56. Faravelli, T.; Frassoldati, A.; Migliavacca, G.; Ranzi, E. Detailed kinetic modeling of the thermal degradation of lignins. Biomass Bioenerg. 2010, 34, 290-301. [CrossRef]

57. Zhang, Y.; Ma, Z.; Zhang, Q.; Wang, J.; Ma, Q.; Yang, Y.; Luo, X.; Zhang, W. Comparison of the physicochemical characteristics of bio-char pyrolyzed from moso bamboo and rice husk with different pyrolysis temperatures. BioResources 2017, 12, 4652-4669. [CrossRef]

58. Kim, J.Y.; Hwang, H.; Oh, S.; Kim, Y.S.; Kim, U.J.; Choi, J.W. Investigation of structural modification and thermal characteristics of lignin after heat treatment. Int. J. Biol. Macromol. 2014, 66, 57-65. [CrossRef]

59. Kato, K.L.; Cameron, R.E. A review of the relationship between thermally accelerated ageing of paper and hornification. Cellulose 1999, 6, 23-40. [CrossRef]

60. Kačík, F.; Šmíra, P.; Kačíková, D.; Vel'ková, V.; Nasswettrová, A.; Vacek, V. Chemical alterations of pine wood saccharides during heat sterilisation. Carbohyd. Polym. 2015, 117, 681-686. [CrossRef]

61. Hrčka, R.; Kučerová, V.; Hýrošová, T. Correlation between Oak Wood Properties. BioResources 2018, 13, 8885-8898. [CrossRef]

62. Prinks, M.J.; Ptasinski, K.J.; Jansen, F.J.J.G. Torrefection of wood, part 2. Analysis of products. J. Anal. Appl. Pyrol. 2006, 77, 35-40. [CrossRef]

63. Candelier, K.; Thevenon, M.F.; Petrissans, A.; Dumarcay, S.; Gerardin, P.; Petrissans, M. Control of wood thermal treatment and its effects on decay resistance: A review. Ann. Sci. 2016, 73, 571. [CrossRef]

(C) 2020 by the authors. Licensee MDPI, Basel, Switzerland. This article is an open access article distributed under the terms and conditions of the Creative Commons Attribution (CC BY) license (http://creativecommons.org/licenses/by/4.0/). 